\title{
THE OPTIMAL CAPITAL STRUCTURE FOR POLISH ACQUIRING COMPANIES - THE PRODUCTION SECTOR
}

\author{
Piotr Luty ${ }^{1 *}$, \\ llona Fałat-Kilijańska', \\ Roman Vavrek
}

${ }^{1}$ Wroclaw University of Economics, Wroclaw, Poland

${ }^{2}$ Presov University in Presov, Presov, Slovakia

\begin{abstract}
:
The paper explores the viability of a theoretical construct of an optimal structure of financing for Polish receiving companies in preparation for their acquisitions. The study was based on a sample of Polish receiving companies operating in the production sector in the period of $2002-2013$ and applied to periods of 1 year prior to the planned merger or acquisition. The research employed instruments of statistical analysis, with focus on linear and multinomial regression. The findings seem to confirm the utility of a theoretical construct representing a structure of capital deemed optimal to ensure an increase in asset operating profitability.
\end{abstract}

Keywords:

mergers, acquisition, capital structure, leverage

\section{INTRODUCTION}

The paper explores the notion of a theoretical optimal level of financing for companies preparing to receive M\&A benefits. The term 'optimal level', for our purposes, should not be interpreted in terms of an M\&A success or failure. For this reason, the research group did not include those companies where M\&A plans were eventually put on hold. The optimal level of financing is defined here as a financing structure that offers best increase in asset profitability. Mergers and acquisition do not come instantaneously - those processes require lengthy preparations for all the actors involved. From the viewpoint of the Polish Code of Commercial Companies - a statutory act regulating, among other things, the formal and legislative aspects of mergers and acquisitions - such processes may be settled based on a transfer of shares or stocks to the new owner. The share exchange ratios defined in negotiations between the trading parties may be related to income levels reported by the merging companies. For this purpose, the negotiating parties may choose to influence the outcome through a skilful use of their capital structure (debt levels) to present an increase in financial result and, consequently, an increase in their reported asset profitability ratios. Based on literature studies, two theoretical approaches to the task at hand can be seen as the most important here, namely: the trade-off theory and the pecking order theory. In accordance with the trade-off theory, in choosing their approach to financing of economic operations, companies should balance their benefits (e.g. those related to the tax shield) against the risk of insolvency or bankruptcy produced by further debt increase. On the other hand, companies in stable financial positions may prefer to retain parts of their profits to finance their operations, rather than rely on debt financing (the pecking order theory). Thus, it may be assumed that debt contracting may be an appealing solution for companies to a certain point, but the most profitable companies and those with
Correspondence:

Piotr Luty

e-mail:

piotr.luty@ue.wroc.pl 
strong development perspectives may display preference for own equity financing. In view of the above, the central research hypothesis of this study is formulated as follows:

$\mathrm{H} 1$ : there is an optimal structure of financing for companies to be pursued one year prior to the planned transformation of ownership

\section{LITERATURE STUDIES}

Professional literature defines capital structure in terms of a financial leverage. This is, naturally, a simplification, commonly adopted in scientific studies. In principle, a financial leverage represents an impact made by a company's financial policy upon the generated financial result. The leverage phenomenon involves an increased reliance on external sources of financing for the increase in reported financial result. In practice, this means that any increase or decrease in the volume of external capital involvement will produce an appositely multiplied increase or decrease in reported financial result. Capital structure, on the other hand, is a measure of a company's approach to financial policy. There are many methods for measuring company capital structure. The most popular ${ }^{1}$, and at the same time - the most intuitive - measure defines it as a share of third party capital in total capital. Evaluation of capital structure should involve proper identification of sources of financial information. Financial data may come from the market or be derived from financial reports. The use of market data can only be applied to companies listed with regulated capital markets; for the majority of companies, however (and for the majority of mergers), market data is not available. This means that financial reports are the only viable source of financial information on companies under study. The most fundamental difference between market information and that from financial disclosures lies in information potential offered by each type of data. Bookkeeping records are mostly historical in content, and are used to measure past events registered for the previous reporting period. Market data, on the other hand, supplement the above with information on future activities and development plans. The choice of data type is thus defined by the composition of the research sample - in our case; the majority of companies were not listed with any regulated capital market. Another argument in favour of bookkeeping records as a basis for this study's evaluation comes from conclusions made from literature studies, namely the oft-reported low statistical significance of differences between market values and bookkeeping values, and the high correlation between bookkeeping and market values of debts (Haas, Peeters (2004)).

In line with the trade-off theory, the optimal capital structure of companies represents a trade-off between

1 After T.Berent. benefits and costs. The theory was pioneered by Modigliani and Miller (1963) and later developed by Kraus and Litzenberger (1973), and Bradley (1984). Further developments included observations that company capital structure may also be related to company development plans, such as new investments. Companies may, by power of their owners' decision, receive new capital in the form of retained profits, with the view of improving the return rates. In cases like this, the share of external capital in more profitable companies will be notably lower. On the other hand, capital retention instruments are not included in the income tax base as due from company owners. New perspectives for balancing the costs and benefits offered by the use of third-party capital are explored, among others, by Hennessy (2005) and Welch (2004).

Further explorations of capital structure in economic entities were strongly affected by the introduction of the concept of information asymmetry in economy. With large asymmetry, creditors will demand more interest, and this will lead to increase in capital cost. The information asymmetry may be reduced by increasing the frequency of forecasts and of the financial reports used to confirm their effects. However, this requirement is only formally expected from public companies listed on regulated capital markets. The steep cost of external capital acquisition has the effect of making companies more inclined to use own assets to finance their operating and development activities (i.e. assets from retained profits) before they decide to seek additional support from third-party providers of capital.

A positive correlation between financing structure and financial result may suggest the use of the trade-off theory, while the pecking order theory may be more suitable in cases where this correlation is negative. In a study by Dufour et al (2017), conducted on a sample of French companies, the authors observed a negative correlation between capital structure and company profitability. The results were confirmed in Placin-Sanchez (2013). This may suggest that profitable companies are generally less burdened with third-party obligations.

\section{METHODOLOGY AND FINDINGS}

For the purpose of the study, the author employed a database of companies produced by InfoCredit S.A. at the commission of the Bookkeepers' Association in Poland. The database contained information on company mergers formally registered with the National Court Register of companies. In line with pending legislation, receiving companies are obliged to report any such ownership transformations to the authority of the National Court Register. This mechanism was designed to allow for automatic exclusion of entries related to companies identified 
as being acquired - they are removed from the register immediately after the conclusion of the merger, and their rights and obligations are transferred to the receiving company. Mergers offer the benefit of avoiding the burden of company liquidation procedures. Under the Polish law (the Code of Commercial Companies), merger procedures require only a transfer of ownership titles from the company being acquired to the receiving company as its immediate successor. The above regulation applies to all mergers, with the only exception being mergers of companies that remain in the same capital relation - to avoid situations where the receiving company issues own shares and stocks only to transfer them to itself.

The study focused on timeframes proceeding the moment of merger. Since the study represents a preliminary examination, the author decided to reduce the standard timeframe coverage of 5 years prior to merger and concentrate on the final phase of the preparation process, i.e. one year prior to merger.

The research sample comprised of 105 companies. Of these, 17 observations were excluded from analyses, as untypical. Thus, the final sample composition included 105 receiving companies of the production sector.

The following variables were used in the study:

$$
\begin{aligned}
& R O A=\frac{\text { NET PROFIT LOSS }}{\text { TOTAL ASSETS }} \\
& L E V=\frac{\text { LIABILITIES }}{\text { TOTAL CAPITAL }}
\end{aligned}
$$

$$
S I Z E=L N(T O T A L \text { ASSETS })
$$

$S A L E S=L N(N E T$ SALES $)$

$$
T A N G=\frac{F I X E D \text { ASSETS }}{\text { TOTAL ASSETS }}
$$

The above list of variables is commonly used in professional literature on the subject. It was employed in capital structure examinations and analyses by Dufur et al. (2017), Zhou et al. (2016), Hussain et al. (2016), PlacinSanchez et al. (2013), Aybar-Aris et al. (2012), Harford, Klasa, Walcott (2008), Haas, Peeters (2004). The above parameters are also used for company description purposes in analyses and research of companies listed on regulated capital markets and in analyses of small and mediumsized enterprises. For these reasons, it may be assumed that the above list of variables will be deemed adequate for our purposes, i.e. for the examination of the postulated research hypothesis.
Based on linear regression analysis for primary data, a model was designed to present correlations between the response variable LEV and the explaining variables ROA, SIZE and SALES - see eq. 6 . The variable describing the sustainability of asset structure was fund statistically insignificant, and as such was excluded from the model.

$$
L E V=-0,605223 \cdot R O A-0,0135493 \cdot S I Z E+
$$$$
0,0666848 \cdot S A L E S
$$

Verifications of model parameters are presented in Tab. 1.

Table 1. Verification of the regression model 1 - all observations

\begin{tabular}{lccccc}
\hline Source & $\begin{array}{c}\text { Sumof } \\
\text { Squares }\end{array}$ & Df & $\begin{array}{c}\text { Mean } \\
\text { Square }\end{array}$ & F-Ratio & P-Value \\
\hline Model & 30.5993 & 3 & 10.1998 & 83.87 & 0.0000 \\
\hline Residual & 11.9177 & 98 & 0.121609 & & \\
\hline Total & 42.5169 & 101 & & & \\
\hline
\end{tabular}

Source: own research

Based on a chart of regression residuals (Chart 1), outliers were removed from the observation set.

Chart 1. Regression residuals for models 1

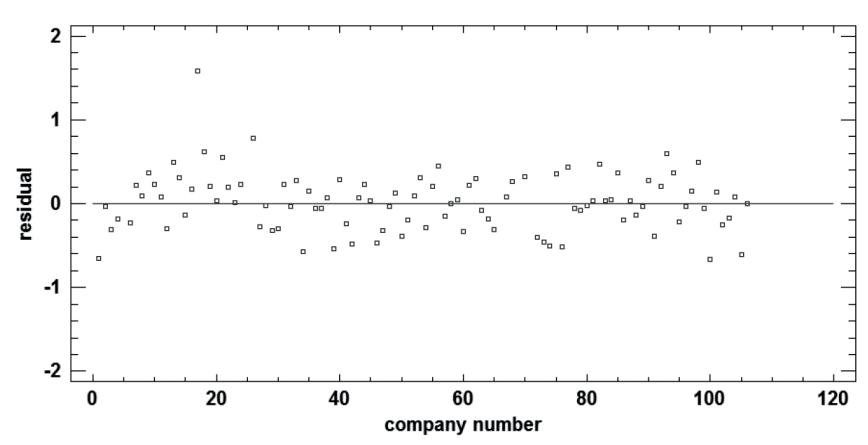

Source: own research

The adjusted database set was then used as basis for another regression analysis procedure, yielding parameters for a regression function presented in eq. 7 .

$$
\begin{aligned}
& L E V=-0,927184 \cdot R O A-0,0031828 \cdot S I Z E+ \\
& 0,0558356 \cdot S A L E S
\end{aligned}
$$

The statistically significant parameters of the regression function are identical with those obtained from the $1^{\text {st }}$ model, but their values are changed. Chart 2 presents correlations between their predicted and empirical values. 
Chart 2. Correlations between their predicted and empirical values

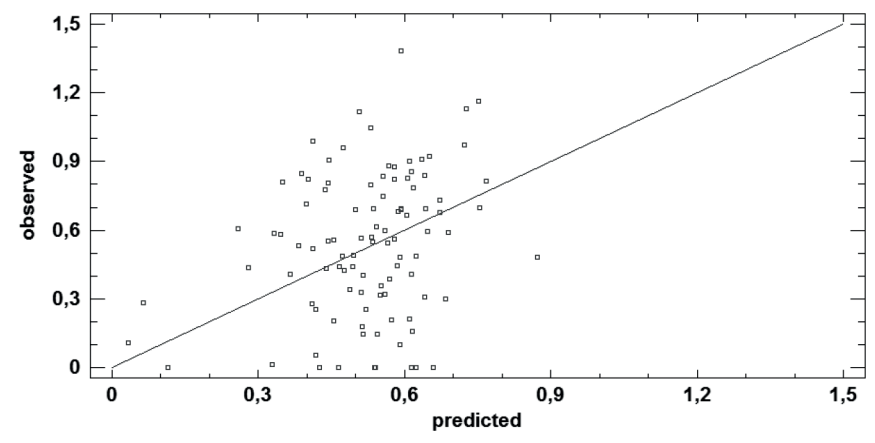

Source: own research

Based on the final model of regression, the author proceeded with verifications of the model's assumptions. Table 2 presents results of these tests.

Table 2. Test of assumptions for the final regression model

\begin{tabular}{lll}
\multicolumn{1}{c}{ Assumption } & \multicolumn{1}{c}{ Test } & \multicolumn{1}{c}{ Result } \\
\hline$\varepsilon_{\mathrm{i}} \sim \mathrm{N}\left(0 ; \sigma_{\varepsilon}^{2}\right)$ & $\mathrm{SW}=0.978, \mathrm{p}=0.469$ & confirm \\
\hline $\mathrm{E}\left(\varepsilon_{\mathrm{i}}\right)=0$ & $\mathrm{~T}\left(\varepsilon_{\mathrm{i}}\right)=-0.435, \mathrm{p}=0.664$ & confirm \\
\hline $\operatorname{cov}\left(\varepsilon_{\mathrm{i}} \varepsilon_{\mathrm{j}}\right)=0$ & $\mathrm{DW}=1.979$ & confirm \\
\hline $\mathrm{D}\left(\varepsilon_{\mathrm{i}}\right)=\sigma_{\varepsilon}^{2}$ & $\mathrm{~L}_{\mathrm{E}}=10 / 10$ & confirm \\
\hline Remote values & Dean Dixon test & confirm \\
\hline
\end{tabular}

Source: own research

Test findings suggest that, in the sample group of Polish receiving companies of the production sector, the LEV indicator of leverage was related to three variables: ROA - return on assets, SIZE - company size measured by balance sheet total, and SALES - company size measured by sales revenues. The adjustment of the model, measured by value of the adjusted $\mathrm{R}^{2}$, was found to be at $76.01 \%$. This means that the three variables under examination were found to explain the fluctuations of the independent response variable LEV at a level of $76 \%$. The value of $\mathrm{R}^{2}$ is high, meaning that the model may viably be employed for prediction of theoretical values of the leverage indicator one year prior to the planned merger.

The next stage of the research procedure was designed to find whether an optimal level of leverage LEV calculated from the model proves to bring the best results in terms of company profitability. For this purpose, for each of the companies under study, prognostics of leverage structure were estimated (LEV predicted) and compared against the empirical values of the leverage index. Negative differences between predicted LEV values and their empirical values would be interpreted to suggest overleveraging (excessive dependence on foreign capital). Positive differences between predicted LEV values and their empirical values, in turn, would be suggestive of underleveraging (too much independence from foreign capital). Each of the two scenarios should be interpreted as proof of inadequate approach to company financial potential or of ineffective adjustment of the companies' financing perspectives. Eq. 8 presents the calculation formula used to examine differences between theoretical and empirical capital structures.

$D L E V=L E V$ Predisted $-L E V$

Based on the findings of predicted and empirical distances between values of capital structure and asset rentability, correlations between the two were established. The ROA variable is a dependent variable, while the distance between theoretical and empirical capita structures is an independent variable. After a preliminary test for the linearity of the regression function, a multinomial (square) regression function was designed, based on a formula presented in eq. 9 below.

$R O A=-0,1275 \cdot D L E V^{2}+0,04815$

The regression function takes the form of an inverted parable, with maximum asset rentability placed at a point where the difference between the theoretical and empirical values of the capital structure indicator reach 0 , suggestive of an optimal level of capital structure, as described in eq. 7 .

\section{CONCLUSIONS}

The purpose of this paper was to examine the potential offered by calculations of optimal financing structure for receiving companies one year prior to the planned merger. The research was conducted on a sample of companies economic entities operating in the production sector. The findings suggest that the companies under study display negative correlation between asset rentability and capital structure. A regression model was construed to establish the statistical significance of parameters and their effects on the capital structure. The model served to establish that the capital structure is dependent on asset rentability (a negative correlation), company size measured by total assets (a negative correlation), and company size measured by sales revenues (a positive correlation). The determination coefficient $\mathrm{R}^{2}$ was found to be at 0.76 , which offered a base for calculations of predicted optimal levels of capital structure. Based on deviations of empirical values of capital structure from those predicted by the model, the 
author was able to examine the effects of any departures from the predicted values in terms of company result. In the light of the regression analysis presented in eq. 9 , it may be observed that the highest yield in asset rentability was associated with those capital structures which closely followed the theoretical (and optimal) levels. Thus, the central research hypothesis has been successfully verified and confirmed.

\section{LITERATURE}

Aybar-Aris, C., Casino-Mart, A., Lopez-Garcia, J., (2012), On the adjustment speed of SMEs to their optimal capital structure, Small Bus.Econ., 39, 977-996

Bradley, M., Jarrell, G., Kim, E., H., (1984), On the existence of optimal capital structure: theory and evidence, Journal of Finance, 39, 857-877

De Haas, R., Peeters, M., The Dynamic Adjustment Towards Target Capital Structures of Firms in Transition Economies. Economics of Transition, Vol. 14, No. 1, pp. 133169, http://dx.doi.org/10.1111/j.1468-0351.2006.00237.x

Dufour, D., Luu, P., Teller, P., (2017), The influence of caschflow on the speed of adjustment to the optimal capital structure, Research in International Business and Finance, 45, 62-71
Harford, J., Klasa, S., Walcott, N., (2008) Do Firms Have Leverage Targets? Evidence from Acquisitions, Journal of Financial Economics, Available at SSRN: https://ssrn. com/abstract $=890849$

Hennessy, C., A., Whited, T., A., (2005), Debt dynamics, Journal of Finance, 60, 1129-1165

Hussain, H., I., Shamsudin, M., F., Jabarullah, N., H., (2016), Non linear speed of adjustment to lead leverage levels ..., Journal of Informatics and Mathematical Sciences, 8, 49-65

Kraus, A., Litzenberger, R., H., (1973), A state-preference model of optimal financial leverage, Journal of Finance, 33, 911-922

Modigliani, F., Miller, M., H., (1963), Corporate income taxes and the cost of capital: a correction, American Economic Review, 53, 433-443

Placin-Sanchez, M., Ramires-Herrera, L., Di Pietro, F., (2013), Capital structure of SMEs in Spanish regions, Small Bus. Econ., 33, 319-333

Welch, I., (2004), Capital structure and stock returns, J.Polit. Econ., 112, 106-131

Zhou, Q., Tan, K.,J.,K., Faff, R., Zhu, Y., (2016), Deviation from target capital structure, cost of equity and speed of adjustment, Journal of Corporate Finance, 39, 99-120 